\title{
Potensi Wakaf di Indonesia (Kontribusi Wakaf dalam Mengurangi Kemiskinan)
}

\author{
Syamsuri, Perdi Fauji Rohman, Aris Stianto \\ Universitas Darussalam Gontor \\ syamsuri@unida.gontor.ac.id,perdi.fauzi@gmail.com, arissetianto2909@gmail.com
}

\section{Article Info}

Article history:

Received Oct19th, 2020

Revised Oct 30th, 2020

Accepted Nov 5th, 2020

\section{Keyword:}

potential of waqf, contribution of waqf, poverty

\begin{abstract}
The discussion of poverty has become a mandatory agenda in every country, including Indonesia. This is evidenced by the budget issued by the government for public welfare. This study will further discuss the potential of waqf in Indonesia as an alternative to reducing poverty in Indonesia. The data collection process is carried out by collecting books, journals, articles, and online sites. The results of the analysis found that Indonesia has a large potential for waqf, this can be seen from the population of Indonesia which is predominantly Muslim, the income occupation sector of Indonesia, and the employment sector of Indonesia's population. In addition endowments can contribute to reducing poverty in Indonesian society through meeting the basic needs of the community, community businesses, and religious communities.

Copyright@2020 Program Studi Ekonomi Syariah Universitas Yudharta Pasuruan All rights reserved.
\end{abstract}

DOI: https://doi.org/10.35891/ml.v12i1.1939

\section{Corresponding Author:}

Syamsuri,

Lecturer at the University of Darussalam Gontor

Email: syamsuri@unida.gontor.ac.id 


\section{A. Pendahuluan}

Wakaf adalah menyerahkan suatu hak milik yang tahan lama (zatnya) kepada seseorang atau nadzir (pengelola wakaf), baik individu maupun badan pengelola dengan syarat hasilnya dipergunakan untuk hal-hal yang sesuai dengan syariat Islam (Soemitra 2019). Dari pengertian ini wakaf memiliki potensi untuk mengembangkan ekonomi umat seperti halnya zakat, infaq, dan sedekah. Wakaf ini erat kaitannya dengan kegiatankegiatan sosial seperti pendidikan, pembangunan masjid, rumah sakit dan lain sebagainya. Bahkan wakaf dapat dijadikan dana abadi yang hasilnya untuk mensejahterakan masyarakat (Medias 2010; Purwaningsih and Susilowati 2020). Wakaf ini jika dihitung dengan jumlah penduduk umat muslim di Indonesia akan sangat berpotensi, mengingat Indonesia merupakan negara dengan jumlah penduduk muslim terbesar.

Indonesia menempati urutan keempat populasi tertinggi di dunia (Worldpopulationreview.com 2019). Berdasarkan data sensus dari pada tahun 2019 jumlah penduduk Indonesia diproyeksikan mencapai 270,625,568 jiwa (Worldpopulationreview.com 2019). Selain itu Indonesia merupakan negara yang mayoritas penduduknya muslim. Adapun presentase tersebut adalah Muslim $87.2 \%$, protestan $6.9 \%$, katolik 2.9\%, hindu $1.7 \%$, Budha $0.7 \%$ dan khonghucu $0.05 \%$ (Worldpopulationreview.com 2019).

Dari sektor pendapatan, Indonesia pada data tahun 2018 mengalami kenaikan. terbukti dengan data Badan Pusat Statistik (BPS) mencatat produk domestik bruto (PDB) perkapita Indonesia naik US\$3.927 setara dengan Rp 56.000.000,-/Tahun pada tahun 2018. Jumlah tersebut naik dari tahun sebelumnya dengan Jumlah Rp 51.900.000,(Suhendra 2019). Dari angka Rp 56.000.000/Tahun jika dibagi 12 Bulan maka penghasilan rata-rata penduduk Indonesia adalah 4.600.000/Bulan.

Sedangkan dari sektor pekerjaan, Badan Pusat Statistik (BPS) mencatat bahwa jumlah penduduk Indonesia yang bekerja pada triwulan I/2018 adalah 127,07 juta orang. Dari jumlah tersebut terbagi menjadi tiga lapangaan pekerjaan terbanyak yaitu pertanian dengan presentase 30,46\% setara dengan 38,70 juta orang, perdagangan dengan 18,53\% setara dengan 23,55 juta orang, dan industri dengan $14,11 \%$ setara dengan 17,92 juta orang (Tirto.id 2020). Dari data Badan Pusat Statistik (BPS) mencatat penduduk miskin Indonesia pada bulan Maret 2018 mencapai 25,95 juta orang.

Jumlah dan Persentase Penduduk Miskin, 2005-Maret 2019

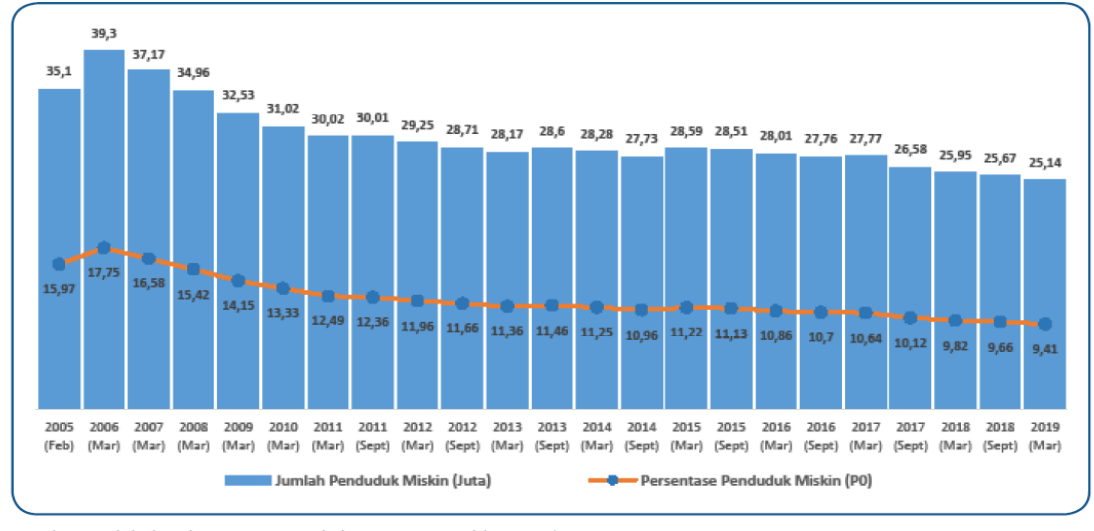

Sumber: Diolah dari data Survei Sosial Ekonomi Nasional (Susenas) 
Dari presentase jumlah penduduk, Indonesia memiliki potensi besar dibidang wakaf untuk menyelesaikan persoalan yang berkaitan dengan ekonomi. Jika penduduk Indonesia sadar akan wakaf dan berwakaf rutin, maka hasil dari wakaf tersebut mampu menyelesaikan masalah-masalah ekonomi dengan mudah, setidaknya kebutuhan pokok penduduk Indonesia sudah tidak lagi kekurangan.

Dalam rangka menciptakan kemakmuran ekonomi perlu adanya strategi dan langkah yang tepat. Strategi dan langkah tersebut harus dapat mengurangi angka kemiskinan dan diterima oleh masyarakat. Dari data Badan Pusat Statistik (BPS) mencatat penduduk miskin Indonesia pada bulan Maret 2018 mencapai 25,95 juta orang. Angka tersebut masih menunjukan tingginya angka kemiskinan di Indonesia.

Keberhasilan pengelolaan wakaf di negara-negara muslim adalah bukti bahwa wakaf sangat berkontribusi dalam menyelesaikan permasalahan ekonomi. Wakaf di Bangladesh sangat menunjukan keberhasilannya. Keberhasilan wakaf tersebut bermula dari ahli ekonomi yaitu M. Abdul Mannan dengan konsep wakaf tunai. Wakaf tunai di Bangladesh sangat berpengaruh dan memiliki arti penting dalam memobilisasi harta wakaf bagi pengembangan wakaf properti. Wakaf tunai tersebut dikembangkan melalui perantara Social Investment Bank Limited (SIBL) dan diserahkan melalui sertifikat wakaf tunai yang akan digunakan untuk instrumen keuangan pada perbankan selaku pengelola harta wakaf, dan hasilnya di manfaatkan untuk peningkatan standar hidup orang miskin, rehabilitas orang cacat, pendidikan, beasiswa dan sosial lainnya.

Di negara Malaysia, wakaf juga menjadi sorotan tersendiri dalam menyelesaikan berbagai persoalan negara. Salah satu yang berkembang di Malaysia adalah suksesnya wakaf yang dialokasikan untuk dana pendidikan. Penelitian yang dilakukan oleh Mustaffa and Muda (2014) menunjukan bahwa wakaf pendidikan di Malaysia tidak hanya memfokuskan pada pusat pendidikan pondok, madrasah, dan sumbangan buku melainkan sudah pada tingkat pengajian tinggi awam dan swasta diantaranya Universiti Islam Antarbangsa Malaysia (UIAM) yang menumbuhkan IIUM Endowment Fund pada tahun 1999, Universiti Kebangsaan Malaysia (UKM) dengan dana wakaf dan endowment UKM pada tahun 2010, Universiti Putra Malaysia (UPM) dengan Dana Wakaf Ilmu UPM pada tahun 2012, serta Universiti Sains Islam Malaysia (USIM) dengan dana wakaf Al-Abrar pada tahun 2013. Selain itu banyak lembaga-lembaga lain yang sudah memulainya dengan wakaf.

Keberhasilan wakaf di Indonesia sudah dirasakan oleh pondok pesantren dan lembaga sosial. Diantara wakaf pondok pesantren tersebut adalah wakaf yang dilaksanakan Pondok Modern Darussalam Gontor (PMDG), TAZAKKA (Rohmaningtyas 2018), Pesantren AL-AMIN PRENDUAN Sumenep Madura dan pondok lainnya (Candra and Amania 2018).

Dari Keberhasilan yang dilakukan oleh beberapa negara tersebut membuktikan bahwa wakaf benar-benar memiliki potensi yang besar untuk dikembangkan. Manfaat yang dihasilkan pun banyak memberikan dampak positif baik di bidang pendidikan maupun ekonomi. Dalam hal ekonomi wakaf dapat digunakan sebagai instrumen untuk mengurangi angka kemiskinan di sebuah negara, mengingat wakaf berpotensi besar jika 
diterapkan. Terbukti dengan riset yang dilakukan oleh pusat penelitian CSRC UIN Syarif Hidayatullah Jakarta pada tahun 2003 yang menyebutkan bahwa tanah wakaf di Indonesia terindentifikasi seluas 154 ha oleh Kementrian Agama, jika dirupiahkan memiliki nilai sebesar Rp590 triliun (Nasrul Fahmi Zaki 2018). Sedangkan menurut Direktorat Pemberdayaan Wakaf pada tahun 2011 menyebutkan bahwa aset tanah wakaf mencapai 2.171.041.349,94 m2 (Nasrul Fahmi Zaki 2018).

Setelah mengidentifikasi potensi wakaf dan melihat angka kemiskinan di Indonesia, maka penelitian ini bertujuan untuk membahas lebih lanjut mengenai kontribusi wakaf dalam mengurangi angka kemiskinan, sehingga masyarakat miskin dapat memenuhi kebutuhan pokok dalam kehidupan sehari-hari. Penelitian ini diharapkan dapat memberikan sedikit bahan pertimbangan wakaf untuk kedepannya.

\section{B. Pembahasan}

1. Wakaf dan Ruang Lingkupnya

a. Definisi wakaf

Wakaf atau Wacf adalah berasal dari bahasa Arab yaitu "Waqafa" yang artinya berhenti, menahan, diam di tempat, atau tetap berdiri. Kata WakafaYaqifu-Waqfan artinya sama seperti Habasa-Yahbisu-Tahbisan (Iqna 2010). kata al-Waqf dalam bahasa Arab mengandung beberapa pengertian

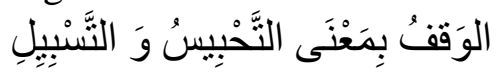

Menahan, menahan harta untuk diwakafkan, tidak dipindahmilikan.

Menurut istilah, terdapat perbedaan pendapat dikalangan ulama dalam mendefinisikan wakaf, adapun pandangan ulama tersebut adalah:

1) Menurut Imam Abu Hanifah

Wakaf berarti menahan suatu benda yang secara hukum tetap milik wakif dalam rangka mempergunakan manfaatnya untuk hal-hal kebajikan. Dari pengertian di atas, kepemilikan harta wakaf tidak terlepas dari wakif, bahkan wakif dibenarkan menarik kembali atau bahkan menjualnya. Apabila wakif telah wafat, maka harta yang wakaf menjadi harta warisan. Dengan demikian, yang menjadi perhatian dari wakaf adalah bagaimana menyumbangkan manfaatnya untuk kebajikan tanpa ada tindakan sesuatu atas benda wakaf (Muhayat 2013).

2) Mazhab Maliki

Dalam mazhab Maliki, wakaf itu tidak melepaskan harta yang diwakafkan dari orang yang berwakaf (wakif), tetapi wakaf tersebut mencegah si wakif untuk melakukan perbuatan yang bisa melepaskan kepemilikannya atas harta wakafnya kepada orang lain selain itu si wakif berkewajiban menyedekahkan manfaat dari harta wakaf dan wakif tidak boleh menarik kembali harta yang telah diwakafkan. Sikap yang diambill wakif ini menjadikan manfaat hartanya untuk di alokasikan kepada rang yang membutuhkkan (penerima wakaf). Wakaf seperti ini bisa dilakukan untuk 
masa tertentu sesuai dengan keinginan oleh si wakif. Misalnya orang yang memiliki rumah sewaan 10 pintu, dan ia mewakafkan 1 pintu dari rumah sewaan tersebut. pemilik rumah sewaan tersebut tidak melepaskan 1 pintu sewaan begtu saja kepada penyewa rumah, melainkan pemilik sewaan tersebut menahan rumah sewaan tersebut secara kepemilikan, tetapi hasilnya dialokasikan untuk yang membutuhkan (penerima wakaf). Modwl perwakafan ini berlaku untuk suatu masa yang ditentukan, oleh karenanya tidak boleh diisyaratkan sebagai wakaf yang kekal (Siti Mashitoh 2007).

3) Mazhab Syafi'i dan Ahmad bin Hambal

Imam Syafi'i dan Ahmad bin Hambal mendefinisikan wakaf adalah melepaskan harta yang diwakafkan dari kepemilikannya (wakif) setelah sempurnanya akad wakaf. Dalam hal ini si wakif sudah terlepas dari harta yang diwakafkan sehingga tidak boleh melakukan sesuatu terhadap harta wakaf tersebut, seperti halnya si wakif wafat, maka harta yang diwakafkan tidak dapat diwarisi oleh ahli warisnya. Dengan kata lain, mazhab ini melarang melakukan tindakan atas suatu benda yang berstatus sebagai milik Allah, dan dengan menyedekahkan manfaatnya kepada orang lain untuk kemaslahatan (Asytuti 2012).

4) Menurut jumhur Ulama

Dalam jumhur ulama, termasuk ulama syafi'iyah dan ulama Hambaliyah, Imam Abu Yusuf dan Muhammad bin Hasan As Syaibani yang dijelaskan Prof. Drs.H. Asmun Abdurrahman dalam Majlis Tarjih Muhammadiyaah bahwa wakaf merupakan kegiatan menahan hak orang yang berwakaf (wakif) terhadap hartanya yang telah diwakafkan dengan tetapnya benda itu, untuk dimanfaatkan bagi kepentigan umum dan kebaikan dalam rangka mendekatkan diri kepada sang pencipta (Siti Mashitoh 2007). Selain itu mazhab lain yang berpendapat kurang dan lebih sama dengan mazhab Syafi'i dan Ahmad bin Hambal, yang membedakan darinya adalah dari segi kepemilikan atas harta wakaf. Dalam mazhab ini harta wakaf menjadi milik maquf 'alaih (yang diberi wakaf), tetapi mauquf 'alih tidak berhak melakukan suatu tindakan pada harta wakaf tersebut, baik itu menghibahkan, menggadaikan dan menjualnya (Dr. Mohamad Akram Laldin, Dr. Mek Wok Mahmud, and Dr. Mohd. Fuad Sawari 2006).

5) Kompilasi Hukum Islam (KHI)

Di dalam KHI wakaf adalah perbuatan seseorang atau sekelompok orang atau badan hukum yang memisahkan sebagian harta darinya dan melembagakan untuk kepentingan ibadah atau untuk keperluan sosial yang sesuai dengan ajaran Islam (AM 2016).

b. Dasar Hukum Wakaf

Adapun yang mendasari disyariatkannya wakaf adalah: 
..:: Malia: Jurnal Ekonomi Islam Vol. 12 No. 1, Desember 2020 ::..

1) Ayat Al-Qur'an

$$
\text { وَافْعَلُّو ا الْخَيْرَ لَعَلَّكُْْ تُفْلِحُوْنَ (الحجج : } 77 \text { ) }
$$

perbuatlah kebajikan, supaya kamu mendapatkan kemenangan.

(QS: al-Haj: 77)

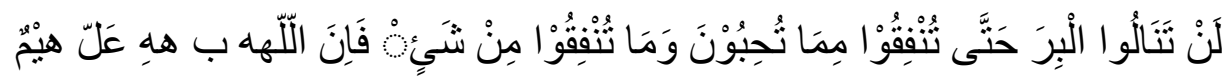

(29: (ال عمران)

Kamu sekali-kali tidak sampai kepada kebaajikan (yang sempurna) sebelum kamu menafkahkan sebagian harta yang kamu cintai. Dan apa saja yang kamu nafkahkan, maka sesungguhnya Allah mengetahui. (QS : Ali-Imran : 92).

2) Hadith

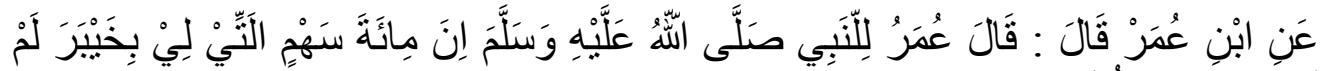

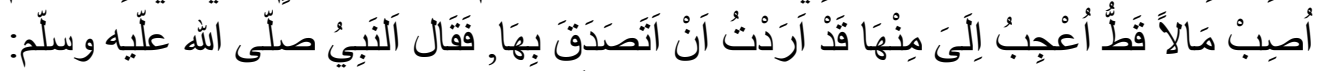

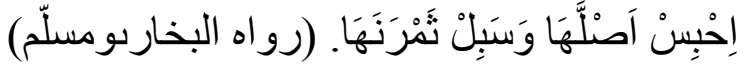

Dari Ibnu Umar, ia berkata : "Umar mengatakan kepada nabi SAW saya mempunyai seratus dirham saham di Khaibar. Saya belum pernah mendapat hartaa yang paling saya kagumi seperti itu. Tetapi saya ingin menyedekahkannya. Nabi SAW mengatakan kepada Umar: tahanlah (jangan jual, hibahkan dan wariskan) asalnya (modal pokoknya) dan jadikan buahnya sedekah untuk sabilillah." (HR.Bukhari dan Muslim).

3) Imam Syafi'i : 80 sahabat ansar semuanya mewakafkan hartanya.

4) Ibnu Hazm : wakaf para sahabat di Madinah lebih dikenal daripada matahari dan tidak seorang pun yang tidak mengetahuinya

2. Potensi wakaf

Wakaf merupakan salah satu dana Phylantropi Islam yang memiliki potensi besar untuk kesejahteraan negara. Potensi tersebut akan efektif jika pengelolaannya dilaksanakan dengan serius, dan potensi tersebut akan menjadi angan-angan jika dikelola dengan tidak serius. Indonesia tergolong negara yang memiliki potensi wakaf terbesar, hal ini dikarenakan jumlah penduduknya yang mayoritas muslim. Presiden Islamic Development Bank (IDB) Ahmad Mohammed Ali Menyampaikan bahwa Badan Wakaf Indonesia (BWI) memiliki potensi sebagai pusat gerakan wakaf di Asia Tenggara. Selain itu beliau menyampaikan agar BWI mendirikan Bank Wakaf untuk negara-negara ASEAN yang kemudian dikelola untuk kemaslahatan bersama (Lita 2017).

Menurut data Kementrian Agama Republik Indonesia, Indonesia memiliki luas tanah wakaf sebesar 48.812,62 ha yang berada di 348.916 titik. Adapun 
penggunaan tanah wakaf sebanyak 44,99\% digunakan untuk masjid, 28,23\% digunakan untuk mushola, 10,59\% digunakan untuk sekolah, 8,40\% digunakan untuk sosial lainnya, 4,59\% digunakan untuk makam dan 3,21\% digunakan untuk pesantren (Hilaliyah and Noer 2018).

Gambar 1. Penggunaan Tanah Wakaf

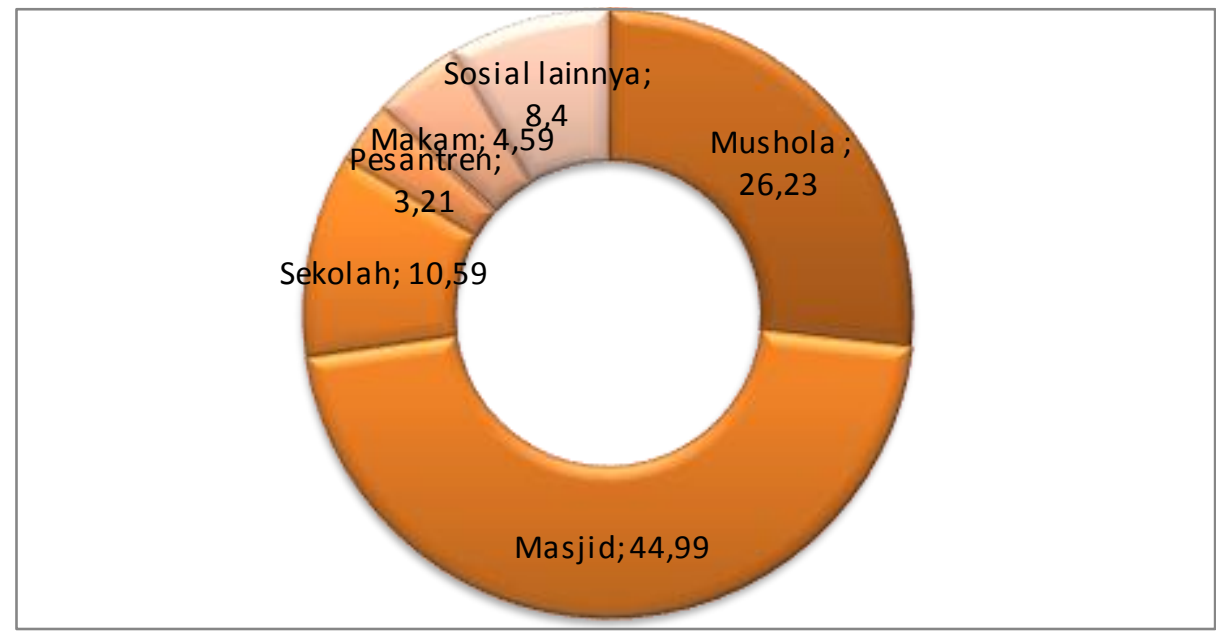

Dalam mendorong percepatan pembangunan, wakaf dapat menjadi salah satu dana sebagai jalan keluar bagi pemerintah untuk memperkuat keuangan negara serta membiayai kebutuhan negara. Seperti halnya peningkatan infrastruktur, kesehatan, pendidikan, dan investasi.

Kaitannya dengan peningkatan infrastruktur, kesehatan, pendidikan, dan investasi, diperlukan wakaf (wakaf tunai/uang) yang dikelola secara baik. Wakaf ini memiliki sifat yang fleksibel sehingga lebih mudah untuk menerapkan atau mengalokasikan kepada sesuatu yang bersifat produktif. Hasil dari dana yang dikelola secara produktif akan digunakan untuk pembangunan baik infrastruktur, kesehatan, pendidikan dan lain sebaginya, sedangkan modalnya masih tetap dan tidak berkurang bahkan akan bertambah jika sebagian di investasikan kembali.

Mustafa Edwin Nasution pernah melakukan asumsi, jika jumlah penduduk Muslim kelas menengah di Indonesia sebanyak 10 juta yang memiliki rata-rata penghasilan perbulan antara Rp 500.000,- Rp 10.000.000,- maka dapat terkumpul sebesar 3 triliun pertahun. Sebagaimana perhitungan dalam tabel berikut (Sukamto 2018):

\begin{tabular}{|l|l|l|l|l|}
\hline $\begin{array}{c}\text { Tingkat } \\
\text { Penghasilan/Bulan }\end{array}$ & $\begin{array}{l}\text { Jumlah } \\
\text { Muslim }\end{array}$ & \multicolumn{1}{|c|}{$\begin{array}{c}\text { Tarif } \\
\text { Wakaf/Bulan }\end{array}$} & $\begin{array}{c}\text { Potensi } \\
\text { Wakaf } \\
\text { Uang/Bulan }\end{array}$ & $\begin{array}{c}\text { Potensi Wakaf } \\
\text { Uang/tahun }\end{array}$ \\
\hline Rp 500.000,- & 4 juta & Rp 5.000,- & Rp 20 Milyar & Rp 240 Milyar \\
\hline $\begin{array}{l}\text { Rp 1 juta - Rp 2 } \\
\text { juta }\end{array}$ & 3 juta & RP 10.000,- & Rp 30 Milyar & Rp 360 Milyar \\
\hline $\begin{array}{l}\text { Rp 2 juta - Rp 5 } \\
\text { juta }\end{array}$ & 2 juta & Rp 50.000,- & $\begin{array}{l}\text { Rp 100 } \\
\text { Milyar }\end{array}$ & Rp 1,2 Triliun \\
\hline
\end{tabular}


..:: Malia: Jurnal Ekonomi Islam Vol. 12 No. 1, Desember 2020 ::..

\begin{tabular}{|l|l|l|l|l|}
\hline $\begin{array}{l}\text { Rp 5 juta - Rp 10 } \\
\text { juta }\end{array}$ & 1 juta & Rp 100.000,- & $\begin{array}{l}\text { Rp 100 } \\
\text { Milyar }\end{array}$ & Rp 1,2 Triliun \\
\hline \multicolumn{3}{|c|}{ Total } & Rp 3 Triliun \\
\hline
\end{tabular}

Tabel. Wakaf Uang di Indonesia

Berikut penjelasan dari tabel di atas:

a. Apabila umat muslim yang berpenghasilan Rp 500.000,- sejumlah 4 juta dan mengeluarkan dana wakaf setiap bulannya sebesar Rp 5.000,- maka setiap tahunnya akan terkumpul sebesar Rp 240 Milyar.

b. Apabila umat muslim yang berpenghasilan Rp 1.000.000,- s/d Rp 2.000.000,sejumlah 3 juta dan mengeluarkan dana wakaf setiap bulannya sebesar Rp 10.000,- maka setiap tahunnya akan terkumpul sebesar Rp 360 Milyar.

c. Apabila umat muslim yang berpenghasilan $\mathrm{Rp} 2.000 .000,-\mathrm{s} / \mathrm{d} \mathrm{Rp} 5.000 .000$,sejumlah 2 juta dan mengeluarkan dana wakaf setiap bulannya sebesar Rp 50.000,- maka setiap tahunnya akan terkumpul sebesar Rp 1,2 Triliun.

d. Apabila umat muslim yang berpenghasilan Rp 5.000.000,- s/d Rp 10.000.000,sejumlah 1 juta dan mengeluarkan dana wakaf setiap bulannya sebesar Rp 100.000,- maka setiap tahunnya akan terkumpul sebesar Rp 1,2 .

Dari perhitungan di atas maka jumlah keseluruhan potensi dana wakaf yang dimiliki adalah sebesar Rp 3 Triliun.

3. Wakaf dan Jaminan Sosial

Sistem jaminan sosial merupakan sebuah program untuk mewujudkan keadilan sosial. Adanya sistem jaminan sosial dapat membantu pembangunan nasional yang berkelanjutan di suatu negara, terlebih di negara-negara berkembang. Dalam pengaturannya sistem jaminan sosial terdiri dari jaminan kesehatan, pensiun, dan dana kematian. Undang-undang No. 40 Tahun 2004 tentang Jaminan Sosial Nasional menyebutkan

" Jaminan sosial adalah perlindungan sosial untuk menjamin seluruh rakyat agar dapat memenuhi kebutuhan dasar hidupnya yang layak dan meningkatkan martabat hidupnya"

Adanya wakaf dalam Islam selain untuk mendapatkan keridhaan dan pahala dari Allah, juga sebagai ibadah sosial kepada manusia. Wujud wakaf dalam ibadah sosial berupa pemberdayaan masyarakat, jaminan sosial, kesehatan, pendidikan, pertanian, peternakan, dan lain-lain. Konsep ini menandakan bahwa Islam telah memikirkan solusi permasalahan ketimpangan sosial di masyarakat, sebelum adanya konsep jaminan dari barat yang dianggap sebagai solusi yang tepat (barat) dalam menyelesaikan ketimpangan di masyarakat.

Harta wakaf terbagi menjadi dua yaitu harta wakaf bergerak dan harta wakaf tidak bergerak (Ghozilah 2019). Salah satu dari harta wakaf bergerak adalah wakaf uang. Wakaf uang dalam pengelolaannya lebih dinamis untuk digunakan dalam 
mengatasi masalah ketimpangan sosial. Dengan adanya wakaf uang diharapkan menjadi alat untuk memberdayakan masyarakat dan menyelesaikan ketimpangan sosial, sehingga masyarakat terpenuhi kebutuhannya.

\section{Konsep kemiskinan}

a. Pengertian Kemiskinan

Kata miskin dalam Bahasa Arab yaitu العأس artinya kesulitan, السائل artinya meminta, الضعيف artinya lemah, العائلة artinya membutuhkan, الفقر artinya hilangnya salah satu anggota badan/fakir, القانع artinya meminta yang merasa ridha/tidak mendesak, المحروم artinya mencegah, الإملاق artinya lemas (Rofiq 2018). Di dalam Al-Qur'an kata miskin disebutkan sebanyak 11 kali kata masakin (jama') disebut sebanyak 12 kali. Banyaknya kata miskin dalam AlQur'an membuktikan bahwa dampak terhadap kemiskinan sangat besar, namun di lain sisi Al-Qur'an memberikan jawaban terhadap dampak kemiskina tersebut.

Badan pusat statistik mengukur kemiskinan dengan menggunakan konsep Basic Needs Aroach. Dalam pendekatan ini kemiskinan berarti ketidakmampuan secara ekonomi dalam memenuhi kebutuhan pokoknya dan pengeluaran. Sehingga dapat dikatakan bahwa orang miskin adalah orang yang memiliki ratarata penghasilan di bawah pendapatan perkapita (Sucipto 2018).

Dalam ilmu fikih, Sayid Sabiq mengatakan orang yang fakir adalah orang yang tidak memiliki harta sebanyak satu nisab (sejumlah minimal harta kekayaan yang harus dikeluarkan zakatnya dalam waktu tertentu). hal ini dapat di pahami dari hadis Rasulullah SAW yang diriwayatkan oleh Mu'az bin Jabal "diambil dari harta orang-orang kaya dan diberikan kepada orang-orang fakir." Dari hadis ini ulama fikih memahami bahwa orang yang memiliki harta sebanyak satu nisab zakat dikatakan kaya, sedangkan yang kurang dinamakan fakir (Sucipto 2018).

b. Kemiskinan dalam Islam

Islam sebagai agama yang universal telah memerhatikan segala asek, baik spiritual dan material (Nasrul Fahmi Zaki 2018). Dari aspek spiritual Islam mengajarkan bagaimana menjaga hubungan diri sendiri dengan yang maha tinggi, sedangkan dari aspek material Islam mengajarkan bagaimana mengelola Sumber daya alam yang baik dan konsep filantropi dalam Islam. Sehingga keduanya tidak mungkin untuk diisahkan antara ekonomi dan agama. Apabila terjadi kemiskinan bukanlah terbatasnya sumber daya alam, tetapi terbatasnya kemampuan seseorang untuk mengelola sumber daya alam tersebut.

Menurut Irfan Sauqi yang dikuti oleh Syamsuri dalam bukunya "Ekonomi pembangunan Islam" mengatakan kemiskinan material adalah alasan yang berkaitan dengan ekonomi seseorang yaitu ketidakmampuan seseorang dalam membiayai kebutuhan pokok, sedangkan kemiskinan spiritual adalah lemahnya pengetahuan dan pemahaman terhadap agama karena nafsu atau ajaran yang menyimpang seperti sekulerisme dan liberalisme (Masyhuri (Pusat Penelitian 
Ekonomi 2019). Hal ini diperkuat oleh Shabri Abd. Majid yang mengikuti pendapat Irfan ul-Haq, mengenai indikator penyebab kemiskinan jika dilihat dari nash, maka terdaat 8 penyebab yaitu (Nasrul Fahmi Zaki 2018):

1) Ketidaktaatan umat muslim terhadap ajaran ilahi. Misalnya mengambil hak anak yatim sehingga anak yatim jadi terlantar.

2) Kemiskinan terjadi disebabkan ulah tangan manusia sendiri terhadap pengelolaan sumber daya alam.

3) Kemiskinan disebabkan oleh keangkuhan sekelompok orang yang diberikan kelebihan oleh Allah SWT untuk menunaikan haknya orang miskin.

4) Kemiskinan disebabkan oleh eksplorasi sumber daya alam oleh sekelompok orang.

5) Kemiskinan yang disebabkan karena malasnya seseorang untuk bekerja atau mencari nafkah untuk keluarganya.

6) Kemiskinan disebabkan akibat fokus kepada kekuasaan politik dan ekonomi pada golongan tertentu.

7) Kemiskinan terjadi akibat pengeksloitasian dan penindasan dalam aspek sosial, politik, dan ekonomi oleh golongan tertentu kepada golongan lain.

8) Kemiskinan terjadi akibat perang.

9)

5. Kontribusi wakaf dalam mengurangi kemiskinan

Dana wakaf yang dikelola dengan baik akan menghasilkan manfaat yang besar bagi kesejahteraan masyarakat. Kemanfaatan yang diperoleh dari dana wakaf kemudian didayagunakan untuk mengurangi kemiskinan disuatu daerah. Dalam mengurangi kemiskinan salah satu jalannya adalah dengan memenuhi kebutuhan masyarakat. Hal ini disebutkan dalam Al-Qur'an surat Yusuf ayat 47-48:

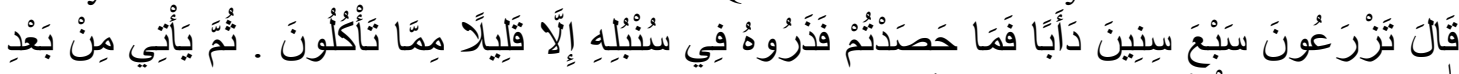

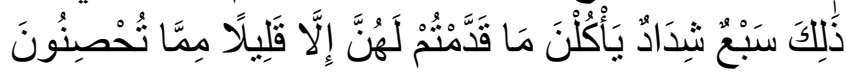

Yusuf berkata: "Supaya kamu bertanam tujuh tahun (lamanya) sebagaimana biasa; maka apa yang kamu tuai hendaklah kamu biarkan dibulirnya kecuali sedikit untuk kamu makan. Kemudian sesudah itu akan datang tujuh tahun yang amat sulit, yang menghabiskan apa yang kamu simpan untuk menghadapinya (tahun sulit), kecuali sedikit dari (bibit gandum) yang kamu simpan."

Ayat ini menegaskan bahwa, manusia perlu mempersiapkan kondisi sulit dalam memenuhi kebutuhannya, sehingga perlu adanya penyimpanan makanan pokok untuk kedepannya. Dengan adanya kondisi seperti ini maka pemerintah dan stake holder yang ada perlu mempersiapkan arahan dan kebijakan untuk menanggulangi ketika terjadi demikian atau untuk mengurangi kamiskinan yang terjadi seperti sekarang ini.

Salah satu langkah untuk mempersipakan hal itu adalah dengan pengelolaan dana wakaf produktif. Hasil dari dana wakaf tersebut kemudian untuk mengurangi 
kemiskinan dengan memaksimalkan kebutuhan masyarakat secara umum. Ini diharapkan angka kemiskinan dapat berkurang dengan cara memenuhi kebutuhan pokok masyarakat yang bersumber dari hasil dana wakaf. Adapun hasil dana wakaf dapat didayagunakan kepada masyarakat dalam bentuk :

a. Pembiayaan kepada masyarakat

Dalam hal pembiayaan kepada masyarakat, dana wakaf dapat diberikan kepada masyarakat berupa penambahan modal untuk pelaku usaha yang telah berjalan. Dana wakaf yang diberikan kepada pelaku usaha ini murni dana pinjaman (Qard al-Hasan) tanpa ada bunga yang dibebankan kepada pelaku usaha, hal ini untuk memudahkan dan meringankan pelaku usaha. Dalam transaksi ini pelaku usaha yang akan diberikan dana wakaf adalah orang yang sudah menjalankan usahanya namun masih belum ada kemajuan pada usahanya. Dana ini tidak diberikan kepada masyarakat yang baru memulai usahanya dan pelaku usaha yang baru membuka usaha, ini dikarenakan dana yang diberikan tidak sepenuhnya untuk membiayai usahanya mulai dari awal, namun hanya membantu jika terjadi kekurangan dana atau manambah usaha yang dilakukannya.

Selanjutnya tugas dari lembaga wakaf adalah memberikan pelayanan kepada pelaku usaha. Pelayanan yang diberikan berupa pelatihan-pelatihan, menyediakan jasa konsultasi usaha, memfasilitasi dalam meningkatkan kualitas produk usaha, dan mengontrol kegiatan dari para pelaku usaha sesuai dengan ajaran Islam. Program ini sesuai dengan pendapat Masyita yang mengatakan bahwa " dana wakaf uang dapat diinvestasikan dan disalurkan untuk memberdayakan masyarakat kecil melalui micro finance dan pendampingan usaha."(Haryanto 2012) Sehingga dengan adanya dana wakaf ini, para pelaku usaha tidak kebingungan dalam menjalankan usahanya baik dari modal maupun manajemen terbarukan dengan situasi dan kondisi serta tantangan dalam berwirausaha.

b. Pembangunan perusahaan air bersih

Air merupakan kebutuhan dasar manusia dalam memenuhi kebutuhannya. Air selain untuk memenuhi kebutuhan dasar manusia seperti sumber air minum dan campuran dalam mengolah makanan, juga sebagai sarana untuk bersuci dari hadas besar dan hadis kecil. Bagi seorang muslim banyak aktivitas yang berkaitan dengan air yaitu sebagai pembersih diri serta lingkungan demi menjaga kesehatan dan menghindari dari penyakit. Sehingga para ulama salaf maupun ulama kontemporer menyerukan untuk memenuhi kebutuhan air bagi daerah atau sekelompok orang yang kekurangan air. Dengan demikian memenuhi kebutuhan air bersih harus mendapatkan perhatian yang serius.

Melihat pentingnya pemenuhan kebutuhan dasar manusia yaitu air, MUI menetapkan fatwanya no. 001/MUNAS-IX/MUI/2015 tentang pendayagunaan harta zakat, infaq, sedakah \& wakaf untuk pembangunan sarana air bersih dan sanitasi masyarakat. Dengan fatwa tersebut, terdapat kekompakan antara para 
ulama dan pemerintah untuk saling memberikan edukasi dan pendidikan kepada masyarakat dalam mewakafkan hartanya untuk hal yang bersifat produktif dan mendasar.

Dalam hal ini hasil dana wakaf dialokasikan untuk membangun perusahaan air bersih atau sejenisnya. Ini dimaksudkan agar kebutuhan pokok manusia berupa air dapat terpenuhi secara terus menerus khususnya dibagian dataran tinggi yang sering kekurangan air bersih. Dengan adanya perusahaan air bersih yang dibangun dari hasil dana wakaf maka masyarakat bisa lebih menerima manfaatnya seperti air menjadi murah karena mendapat subsidi dari perusahaan tersebut, kebutuhan air selalu terpenuhi, dan masyarakat mendapat pekerjaan untuk mengelola perusahaan tersebut.

Begitu juga dengan dibangunnya perusahaan Listrik, listrik pada zaman sekarang menjadi kebutuhan dasar masyarakat. Dengan dibangunnya perusahaan listrik dari hasil dana wakaf, masyarakat bisa lebih meminimalisir pengeluaran dana listrik untuk memenuhi kebutuhannya.

c. Lahan Pertanian

Pertanian di Indonesia saat ini masih menjadi ruang kerja bagi masyarakat kebanyakan, terbukti dengan hampir separuh penduduk Indonesia berpendapatan dari pertanian. Dengan adanya hal ini pertanian memiliki potensi besar untuk dikembangkan dan menjadi penghasilan masyarakat kebanyakan yang dikelola atas dana wakaf.

Hasil dana wakaf yang dialokasikan ke pertanian akan menjadi jawaban bagi masyarakat yang hidup berada dibawah angka kemiskinan. Dengan adanya pengalokasian tersebut masyarakat memiliki sumber penghasilan sehingga tidak harus mencari pekerjaan lain, tetap fokus pada pengembangan pertanian. Masyarakat tidak akan kekurangan makanan pokok untuk memenuhi kebutuhan sehari-hari karena sudah ditopang dengan hasil pertaniannya sendiri, bagi yang yang tidak memiliki lahan akan menerima manfaatnya berupa murahnya harga kebutuhan pokok tersebut.

d. Pendidikan

Pendidikan merupakan hal penting dalam meningkatkan kesejahteraan masyarakat. Dengan adanya peningkatan pendidikan tersebut masyarakat akan lebih cerdas, beradab, mampu memilih mana yang baik dan mana yang buruk, apa yang harus dilakukan dan apa yang harus di tinggalkan, hingga berfikir kedepan semua orang harus mendapatkan pendidikan yang baik.

Hasil dana wakaf dapat dialokasikan untuk pendidikan seperti pemberian beasiswa kepada anak yang berprestasi dan miskin, pembangunan kampus dan sarana prasarananya, serta hal lain yang menunjang pendidikan.

e. Keagamaan

Dalam hal keagamaan, hasil dana wakaf dapat digunakan untuk meneguhkan keimanan masyarakat dan membangun sumber daya manusia yang berkualitas. Meneguhkkan keimanan masyarakat bisa dilalui dengan memberikan 
pengajian rutinan masyarakat agar merasa bangga menjadi seorang muslim, dan membangun sumber daya manusia dilalui dengan pendampingan, pembiayaan, dan kaderisasi untuk mewujudkan manusia yang berkontribusi untuk masyarakat lainnya dalam segala bidang sesuai dengan prinsip syariah.

Dari penjelasan di atas, dapat disimpulkan bahwa hasil dana wakaf sangat berkontribusi dalam mengurangi kemiskinan yang melanda masyarakat. Mengingat potensi wakaf di Indonesia sangat besar, hal ini terlihat dari mayoritas penduduknya yang beragama Islam. Jika hal ini dimaksimalkan oleh pemerintah atau stake holder pemerintahan maka bisa dipastikan Indonesia bisa sejahtera dengan dana wakaf yang dikumpulkan dan dibagikan secara adil dan merata.

\section{Kesimpulan}

Wakaf di Indonesia memliki potensi besar untuk kesejahteraan masyarakat. hal ini didukung dengan jumlah pennduduk indonesia yang mayoritas muslim, banyaknya aset wakaf yang sudah terdaftar di BWI serta besar wakaf uang jika dikumpulkan secara keseluruhan.

Angka kemiskinan di Indonesia masih terbilang cukup besar yaitu sebanyak 25,95 juta orang yang hidup di bawah angka kemiskinan. Ini merupakan jumlah yang harusnya menjadi perhatian bagi pemerintah dan masyarakat pada khususnya untuk sama sama tolong menolong dalam kebaikan dan membantu dalam memenuhi kebutuhan hidupnya.

Dari besarnya potensi wakaf yang miliki bangsa Indonesia, dan banyaknya jumlah masyarakat yang hidup di bawah garis kemiskinan, maka wakaf dapat menjadi solusi untuk mengurangi angka tersebut. Untuk mengurangi angka tersebut wakaf dapat mengalokasikan dananya dalam bentuk pemenuhan kebutuhan pokok dari masyarakat, sehingga kebutuhan masyarakat dapat terbantu dengan adanya dana wakaf yang dialokasikan kepadanya. 


\section{DAFTAR PUSTAKA}

AM, Mufti. 2016. "Pembaharuan Hukum Dalam Kompilasi Hukum Islam Di Indonesia." Jurnal Ilmiah Al-Syir'ah 7, no. 1. https://doi.org/10.30984/as.v7i1.57.

Asytuti, Rinda. 2012. “Optimalisasi Wakaf Produktif.” At-Taradhi Jurnal Study Ekonomi, IAIN Pekalongan 3, no. 1: 45-53.

Candra, Hari, and Naila Amania. 2018. "Peran Lembaga Pendidikan Wakaf Dalam Membentuk Karakter Bertoleransi." ZISWAF : Jurnal Zakat Dan Wakaf 4, no. 2: 263. https://doi.org/10.21043/ziswaf.v4i2.3045.

Dr. Mohamad Akram Laldin, Dr. Mek Wok Mahmud, and Dr. Mohd. Fuad Sawari. 2006. "Maqasid Syariah Dalam Perlaksanaan Wakaf." Konvensyen Wakaf Kebangsaan, 1-16.

Ghozilah, Umi. 2019. "Pengelolaan Wakaf Produktif Untuk Pemberdayaan Ekonomi Umat Di KSPPPS BMT Bina Ummat Sejahtera Lasem Rembang." UIN Wali Songo Semarang.

Haryanto, Rudy. 2012. "Pengentasan Kemiskinan Melalui Pendekatan Wakaf Tunai." AlIhkam 7, no. 1: 178-200. http://www.ejournal.stainpamekasan.ac.id/index.php/ alihkam/article/viewFile/323/314.

Hilaliyah, Lia, and Khaerul Umam Noer. 2018. "Mendorong Produktivitas Lahan Wakaf Di Yayasan Attaqwa: Analisis Bisnis Menggunakan Smini Market Dan Ahp.” Journal of Business and Entrepreneurship 1, no. 1: 1-12.

Iqna. 2010. “Azərbaycanın Təhsil Naziri 'Hicab Qadağandır!' Dedi.” Az. 2010. http://www.iqna.ir/az/news/2045043/azərbaycanın-təhsil-naziri-hicab-qadağandır-dedi-.

Lita, Helza Nova. 2017. "Pengaturan Wakaf Dan Perkembangannya Di Indonesia Menurut Undang-Undang Nomor 41 Tahun 2004 Tentang Wakaf.” Jurnal Al-Awqaf, 1-23.

Masyhuri (Pusat Penelitian Ekonomi, Lembaga Ilmu Pengetahuan Indonesia). 2019. "Ekonomi Syariah Dalam Etika Pemerataan Resiko Syariah." Jurnal Ekonomi Dan Pembangunan 13, no. 2: 114-23.

Medias, Fahmi. 2010. "Wakaf Produktif Dalam Perspektif Ekonomi Islam.” La_Riba 4, no. 1: 71-86. https://doi.org/10.20885/lariba.vol4.iss1.art5.

Muhayat, Imam. 2013. "Lembaga Wakaf: Suatu Solusi Pembiayaan Pendidikan Islam." Edukasi 1, no. 1: 128-38.

Mustaffa, Najibah, and Mohd Zamro Muda. 2014. "Pengurusan Wakaf Pendidikan Di Institusi Pengajian Tinggi Malaysia: Satu Sorotan Literatur." International Journal of Management Studies. https://doi.org/10.32890/ijms.21.2.2014.10412.

Nasrul Fahmi Zaki, Fuadi. 2018. "Wakaf Sebagai Instrumen Ekonomi Pembangunan Islam." Economica: Jurnal Ekonomi Islam 9, no. 1: 151-77.

Purwaningsih, Septi, and Dewi Susilowati. 2020. "Peran Wakaf Dalam Meningkatkan Pemberdayaan Ekonomi Umat." Jurnal Ekonomi, Bisnis Dan Akuntansi (JEBA) 22, no. 2: 191-203. 
Rofiq, M Nafiur. 2018. "Peranan Filsafat Ilmu Bagi Perkembangan Ilmu Pengetahuan." FALASIFA : Jurnal Studi Keislaman 9, no. 1: 161-75. https://doi.org/10.36835/falasifa.v9i1.112.

Rohmaningtyas, Nurwinsyah. 2018. "Pengumpulan Wakaf Berbasis Pesantren: Studi Kasus Di Pondok Modern Darussalam Gontor Dan Pondok Modern Tazakka." Jurnal Ekonomi Syariah 1, no. 1: 1-21. http://kiss.kstudy.com/search/detail_page.asp?key=3424155\%0 Ahttps://doi.org/10.1016/j.rcim.2018.05.010\%0Ahttps://doi.org/10.1016/j.cie.2018.07.0 41.

Siti Mashitoh, Mahamood. 2007. "Pembentukan Dana Wakaf Menurut Perspektif Syariah Dan Undang-Undang Serta." Jurnal Syariah 2: 61-83.

Soemitra, Andri. 2019. “Bank Dan Lembaga Keuangan Syariah.” In Bank Dan Lembaga Keuangan Syariah, 167.

Sucipto, Moch. Cahyo. 2018. "Pembangunan Ekonomi Dalam Perspektif Islam.” Eksisbank: Ekonomi Syariah Dan Bisnis Perbankan 2, no. 1. https://doi.org/10.37726/ee.v2i1.12.

Suhendra. 2012. "Finance.detik.com." Wuih! Kebutuhan Rumah Capai 2,6 Juta Unit per Tahun. 2012. http://finance.detik.com/read/2012/02/16/065221/1843675/1016/wuihkebutuhan-rumah-capai-26-juta-unit-per-tahun.

Sukamto. 2018. "Menuju Era Baru Wakaf Tunai (Sebagai Inovasi Finansial Islam Dalam Mensejahterakan Umat).” Ekonomi Islam 9, no. 2: 193-212.

Tirto.id. 2020. "Update Corona Indonesia: Daftar 20 Wilayah Yang Terapkan PSBB." Tirto.id. 2020. https://tirto.id/update-corona-indonesia-daftar-20-wilayah-yang-terapkanpsbb-ePVK.

Worldpopulationreview.com. 2018. "Liberia Population 2018 (Demographics, Maps, Graphs)." Worldpopulationreview.com. 2018. http://worldpopulationreview.com/ countries/liberia-population/. 
..:: Malia: Jurnal Ekonomi Islam Vol. 12 No. 1, Desember 2020 ::.. 